\title{
Phytoprotection
}

\section{A first record of Pestalotiopsis clavispora in Argan mass cutting propagation: Prevalence, prevention and consequences for plant production \\ Premier signalement de Pestalotiopsis clavispora chez l'arganier en bouturage de masse : prévalence, prévention et conséquences pour la production végétale}

\author{
Mustapha Bakry, Guy Bussières, Mohammed S. Lamhamedi, Hank A. Margolis, \\ Debra C. Stowe, Mohamed Abourouh, Martine Blais et Jean A. Bérubé
}

Volume 90, numéro 3, 2009

URI : https://id.erudit.org/iderudit/045780ar

DOI : https://doi.org/10.7202/045780ar

Aller au sommaire du numéro

Éditeur(s)

Société de protection des plantes du Québec (SPPQ)

ISSN

0031-9511 (imprimé)

1710-1603 (numérique)

Découvrir la revue

Citer cet article

Bakry, M., Bussières, G., Lamhamedi, M. S., Margolis, H. A., Stowe, D. C., Abourouh, M., Blais, M. \& Bérubé, J. A. (2009). A first record of Pestalotiopsis clavispora in Argan mass cutting propagation: Prevalence, prevention and consequences for plant production. Phytoprotection, 90(3), 117-120. https://doi.org/10.7202/045780ar
Résumé de l'article

Deux approches différentes de bouturage de masse d'Argania spinosa ont été utilisées. La première consistait à enraciner les boutures dans des mini-bouturathèques sans brumisation, tandis que la deuxième consistait à utiliser une serre dotée d'un brumisateur. Des symptômes de nécrose des pétioles et de jaunissement des feuilles ainsi qu'une production abondante d'acervules noires ont été observés dans les deux protocoles. Dans les mini-bouturathèques, ces symptômes ont entraîné un taux de mortalité de 90 $\%$ des boutures, alors que sous brumisateur la nécrose précoce et fatale des bourgeons apicaux a engendré 100 \% de mortalité. L’agent causal de la maladie, Pestalotiopsis clavispora, décrit pour la première fois sur les boutures d'arganier, a été identifié à partir de ses caractères morphologiques et par analyse moléculaire. Un traitement hebdomadaire à base de fongicide systémique et de fongicide de contact utilisés en alternance a permis de maîtriser cet agent pathogène avec un taux de réussite de $41 \%$. 


\title{
A first record of Pestalotiopsis clavispora in Argan mass cutting propagation: Prevalence, prevention and consequences for plant production
}

\author{
Mustapha Bakry ${ }^{\natural}$, Guy Bussières ${ }^{1}$, Mohammed S. Lamhamedi², Hank A. Margolis', \\ Debra C. Stowe', Mohamed Abourouh ${ }^{3}$, Martine Blais ${ }^{4}$, and Jean A. Bérubé ${ }^{4}$
}

Received 2010-06-04; accepted 2010-10-22

PHYTOPROTECTION 90 : 117-120

A trial involving the mass propagation of Argania spinosa cuttings was established following two protocols: in mini-bouturathèques without mist and in a greenhouse under mist. Symptoms of petiole necrosis, foliar yellowing and abundant black acervuli were observed under both protocols. These symptoms were responsible for a $90 \%$ mortality rate in the mini-bouturathèques while under the mist treatment premature fatal necrosis of the apical buds resulted in $100 \%$ mortality. The disease's causal agent, Pestalotiopsis clavispora, was identified on the basis of its morphological characteristics and by molecular analysis. Alternating weekly treatments of systemic and contact fungicides resulted in a $41 \%$ success rate in controlling this pathogen, described for the first time on argan cuttings.

Keywords: Argania spinosa, fungicides, Pestalotiopsis clavispora, rooted cuttings.

[Premier signalement de Pestalotiopsis clavispora chez l'arganier en bouturage de masse : prévalence, prévention et conséquences pour la production végétale]

Deux approches différentes de bouturage de masse d'Argania spinosa ont été utilisées. La première consistait à enraciner les boutures dans des mini-bouturathèques sans brumisation, tandis que la deuxième consistait à utiliser une serre dotée d'un brumisateur. Des symptômes de nécrose des pétioles et de jaunissement des feuilles ainsi qu'une production abondante d'acervules noires ont été observés dans les deux protocoles. Dans les mini-bouturathèques, ces symptômes ont entraîné un taux de mortalité de $90 \%$ des boutures, alors que sous brumisateur la nécrose précoce et fatale des bourgeons apicaux a engendré $100 \%$ de mortalité. L'agent causal de la maladie, Pestalotiopsis clavispora, décrit pour la première fois sur les boutures d'arganier, a été identifié à partir de ses caractères morphologiques et par analyse moléculaire. Un traitement hebdomadaire à base de fongicide systémique et de fongicide de contact utilisés en alternance a permis de maîtriser cet agent pathogène avec un taux de réussite de $41 \%$.

Mots clés: Argania spinosa, bouturage, fongicides, Pestalotiopsis clavispora.

The Argan tree (Argania spinosa L. Skeels) is an endemic, multi-purpose tree that plays an important ecological and socio-economic role in the southwestern region of Morocco. The species belongs to the Sapotaceae family and occupies an area of about 820,000 ha in arid and semi-arid zones, constituting the last tree cover facing the largest desert in the world. The Argan tree has the potential to thrive on marginal, infertile dry land, where it is integral to combating the desertification process and produces valuable fruit, fodder and timber. For these reasons, the species has been introduced into several other countries, including Australia, South Africa, Spain, Israel, Egypt and the USA (Nouaim et al. 1993).

To propagate selected genotypes with desirable characteristics, a cutting trial was conducted at Université Laval $\left(46^{\circ} 46^{\prime} \mathrm{N}, 71^{\circ} 16^{\prime} \mathrm{W}\right.$, Québec, QC, Canada). Non-lignified cuttings were taken from 2- and 3-yr-old sturdy stock plants grown from seed in a greenhouse

\footnotetext{
1. Faculté de foresterie, de géographie et de géomatique, Département des sciences du bois et de la forêt, Université Laval, Québec (Québec), Canada G1K 7P4; corresponding author e-mail: mustapha.bakry.1@ulaval.ca, bakry.mustapha@gmail.com

2. Ministère des Ressources naturelles et de la Faune du Québec, Direction de la recherche forestière, Québec (Québec), Canada G1P 3W8

3. Centre de la Recherche Forestière, BP 763, Agdal, Rabat, Morocco

4. Laurentian Forestry Centre, Canadian Forest Service, Natural Resources Canada, Québec (Québec), Canada G1V 4C7
} 
at $25 / 18 \pm 2{ }^{\circ} \mathrm{C}$ (day/night), $75 / 60 \pm 5 \%$ relative humidity, a light intensity of 5000 lux, and a photoperiod of $16 \mathrm{~h}$ light/8h darkness. Cuttings of $5 \mathrm{~cm}$ in length were washed with running tap water, thoroughly disinfected in a $1 \%$ sodium hypochloride solution for $5 \mathrm{~min}$, and rinsed in sterile distilled water. The basal foliage within $2 \mathrm{~cm}$ of the cutting base was removed. After dipping the stem bases in 1000 ppm Indole-3-butyric acid powder (Stim-Root ${ }^{\circledR} \# 1$ ), the cuttings were inserted into multi-cell IPL 67-50 seedling containers (67 cavities of $50 \mathrm{~cm}^{3}$ per container; IPL®, SaintDamien, QC, Canada) filled with a peat:perlite (3:1; v:v) substrate. All tools used to prepare the cuttings were autoclaved for $30 \mathrm{~min}$ at $121^{\circ} \mathrm{C}$ and a pressure of 1 bar. Two experiments, each comprising 360 cuttings, were conducted. Under the first protocol, which was adapted from the system described by Vallée and Noreau (1990), the potted cuttings were enclosed in a mini-bouturathèque system consisting of transparent plastic enclosures that were $73 \mathrm{~cm}$ long, $48 \mathrm{~cm}$ wide and $18 \mathrm{~cm}$ high. These were kept in a greenhouse at $25 / 18^{\circ} \mathrm{C}\left( \pm 1^{\circ} \mathrm{C}\right)$ with a $16-\mathrm{h}$ photoperiod and no misting. The cuttings under the second protocol were placed in a greenhouse equipped with an automatic mist system, maintained at day/night temperatures of $25 / 18^{\circ} \mathrm{C}\left( \pm 1^{\circ} \mathrm{C}\right)$, and a $16-\mathrm{h}$ photoperiod. Under the first protocol, symptoms of petiole necrosis appeared $10 \mathrm{~d}$ after potting, followed by foliage yellowing and premature leaf fall. The disease progressed from foliar browning to an extensive blight, eventually leading to black acervuli production on all affected plant parts, including leaves, thorns and stems. The disease was more severe under the mist treatment. The apical buds quickly succumbed to fatal bud rot followed by wilting of the stem tips and the appearance of all other symptoms observed in the bouturathèque protocol. After $1 \mathrm{mo}$, the mortality rates under the mini-bouturathèque and mist protocols were $90 \%$ and $100 \%$, respectively. On some of the less vigorous stock plants in the greenhouse, minor symptoms of infection (yellowing of leaf margins, scattered brown spots) were observed. However, there was an abundant production of black acervuli on the senescent leaves that had fallen in the pots.

To isolate the pathogen, tissue samples were obtained from symptomatic cuttings and asymptomatic stock plants. Pieces of diseased and healthy tissue measuring approximately $1 \mathrm{~cm}^{2}$ were cut, disinfected in a $1 \%$ sodium hypochlorite $(\mathrm{NaClO})$ solution for $5 \mathrm{~min}$, rinsed in sterile distilled water, blot dried on sterile filter paper, and plated on potato dextrose agar (PDA). Plates were incubated at $22^{\circ} \mathrm{C} \pm 0.5^{\circ} \mathrm{C}$ in darkness. Direct isolations from fungal acervuli were also conducted and successive subcultures were carried out to observe mycelia development. After $20 \mathrm{~d}$ of growth, strain identity was confirmed by microscopic examination of the acervuli and spores. DNA from the isolates was amplified by PCR using universal internal transcribed spacers ITS1-F and ITS4 and an rDNA sequence of regions 1 and 2, which also included the 5.8S rDNA gene. The DNA of kernels extracted from whole surface-sterilized Argan nuts was also amplified using ITS1-F and ITS4.

More than 50 isolates were examined. All of them were identified as Pestalotiopsis clavispora (Atkinson)
Steyaert based on their morphological and cultural characteristics using the keys provided by Guba (1961) and other descriptions previously reported by Keith et al. (2006), Espinosa and Briceno (2008), and Luan et al. (2008). The rDNA ITS sequence from our Pestalotiopsis clavispora P6 isolate was deposited in GenBank (accession number HQ414541). The causal agent was systematically isolated from all diseased cuttings and all incubated asymptomatic stock plant tissue. PDA cultures were white and cottony, became darker with age, and produced abundant, radially distributed acervuli. The conidia were clavate-fusiform with three thick-walled, coloured median cells, one basal cell, and one apical hyaline cell. Five suspensions were prepared, on which 150 conidia were randomly measured (30 per suspension). The five-celled conidia measured 18 to $26 \mu \mathrm{m}(22.98 \pm 0.24 \mu \mathrm{m})$ in length and 6.5 to $8.5 \mu \mathrm{m}(7.81 \pm 0.067 \mu \mathrm{m})$ in width (mean \pm standard error). The conidia had two to four hyaline filiform apical appendages and one hyaline filiform basal appendage. The identity of this pathogenic fungus was also confirmed by the $100 \%$ homology of the 517 bp rDNA ITS sequence obtained with a Pestalotiopsis clavispora isolate from Chile (GenBank EU342214). The DNA from kernels did not reveal the existence of the fungus in the Argan nuts.

To confirm pathogenicity, 30 unrooted 5-cm-long cuttings were collected from 2-mo-old seedlings obtained from sterilized seeds (15 min in pure sulfuric acid and $10 \mathrm{~min}$ in a solution of hydrogen peroxide $30 \%$ volume) grown under axenic conditions. The cuttings were prepared as previously described and were wound-inoculated with $3 \mu \mathrm{L}$ of a suspension of ground mycelia. The 30 cuttings under the control treatment were wounded in the same manner and inoculated with $3 \mu \mathrm{L}$ of sterile distilled water. The pathogenicity test was conducted in a sterile minibouturathèque system maintained at day/night temperatures of $25 / 18^{\circ} \mathrm{C}\left( \pm 1^{\circ} \mathrm{C}\right)$ and a 16 -h photoperiod. After $18 \mathrm{~d}$, symptoms similar to those observed under the two original experimental protocols were noted. The control cuttings remained healthy after 1 mo of incubation, again demonstrating that the fungus does not originate from the seeds. To fulfill Koch's postulates, pieces from the diseased and symptom-free cuttings were disinfected and plated on PDA. The isolates from the diseased cuttings were identified as Pestalotiopsis clavispora based on their colony and conidial morphologies. In the Petri dishes containing symptom-free tissue, no culture was observed.

Both the absence of the pathogen in the Argan seeds and the removal of the epiphytes through surface disinfection of the cuttings (Zhang et al. 1997) led us to conclude that the $P$. clavispora cutting infection is transferred as an endophyte through the vegetative propagules of the naturally infected stock plants by this cosmopolitan fungus (Saar et al. 2001).

Furthermore, the limited and scattered appearance of symptoms on the stock plants indicates that $P$. clavispora maintained an opportunistic and endophytic relationship with its host, developing as saprophyte on senescent, fallen leaves. During the rooting phase, its virulence became evident. The stress level of unrooted cuttings and the favourable environmental conditions of the mass cutting propagation system 
contributed to widespread fungal infection. It should be noted that Espinosa and Briceno (2008) considered $P$. clavispora to be a primary pathogen of blueberry in Chile, while Keith et al. (2006) associated it with guava scabby fruit disease in Hawaii.

To control this disease, a cutting trial with and without fungicide treatment was conducted. The experimental protocol consisted of two groups of 60 cuttings. The first group remained untreated and served as a control, whereas the second group was treated with a systemic fungicide Nova 40W (40\% Myclobutanil) at a dose of $0.4 \mathrm{~g} \mathrm{~L}^{-1}$ and a contact fungicide Manzate (75\% Mancozeb) at a dose of $3 \mathrm{~g} \mathrm{~L}^{-1}$ on alternate wk throughout the experimental period. The weekly treatments began with the application of the systemic fungicide when the protocol was launched. The contact fungicide, Mancozeb, was first applied $1 \mathrm{wk}$ later. The cuttings were sprayed just to the limit of runoff. The total quantities of fungicides applied were $0.6 \mathrm{~g} \mathrm{~m}^{-2}$ of Manzate (Mancozeb) and $0.06 \mathrm{~g} \mathrm{~m}^{-2}$ of Nova 40W (Myclobutanil).

After 1 mo of culture, all of the cuttings in the control treatment had died, while only $5 \%$ of the treated cuttings were dead. After 4 mo of culture, $41.6 \%$ of the treated seedlings were still alive; $33.3 \%$ had rooted, $5 \%$ had formed calluses and 3.3\% remained unrooted. The rooting results of this preliminary test showed a relatively efficient control of the disease, compared with the $41 \%$ success rate achieved by Bellefontaine et al. (2010) in Morocco. One way to increase disease containment would be to use fungicides more specific to $P$. clavispora and to treat stock plants before cutting removal.

Several studies have shown that successful Pestalotiopsis infection cannot be established without first artificially wounding its host (Espinosa and Briceno 2008; McQuilken and Hopkins 2004). Since vegetative propagation involves cutting of vegetative propagules, and therefore results in wounding, a fungicide treatment scheme should be integrated into the mass propagation cutting system. This is particularly important in the case of Argan cuttings that remain unrooted for more than 3 mo, which significantly increases the risk of infection. Furthermore, Pestalotiopsis species exhibit a wide variety of relationships with their hosts. They have been reported to be saprobes, endophytes and facultative pathogens (Hu et al. 2007; Metz et al. 2000), are ubiquitous in distribution and are found on a wide range of substrates (Jeewon et al. 2003; Thaung 2008). Also, they are not host-specific (Hu et al. 2007) and can thrive over a wide range of temperatures, $\mathrm{pH}$ and matric potentials (Hopkins and McQuilken 2000; McQuilken and Hopkins 2004), indicating that they are adapted to a range of environmental conditions. Pestalotiopsis clavispora is associated with many plant species growing in various parts of the world (Morgan et al. 1998; USDA 2009), including South Africa, Australia, the USA and Egypt, where Argania spinosa has already been introduced. To our knowledge, this is the first report of disease caused by $P$. clavispora on Moroccan argan tree cuttings. Considering the global distribution of this pathogen, its ecological plasticity, its ability to thrive under various environmental conditions and its virulence during the rooting phase of mass cutting propagation, there is a risk that $P$. clavispora infections could become a serious problem in breeding programs across Argania spinosa's entire range of distribution. Based on the results of the present study, we recommend including a fungicide treatment scheme in all Argania spinosa mass cutting propagation systems, both within and outside its native range, to protect vegetative propagules from infection.

\section{ACKNOWLEDGMENTS}

The authors thank Louis Bernier (Université Laval) for his critical reading of the manuscript. We are also grateful to Yves Piché, Annie Champagne, Josée Dufour, Carole Coursolle, François Larochelle and Paul Desaulniers (Université Laval) for their logistical and technical assistance. Marie Simard (forest pathology group, Laurentian Forestry Centre) and Mario Renaud, Linda Veilleux and Pascal Desjardins (Direction de la recherche forestière, ministère des Ressources naturelles et de la Faune du Québec), were also integral to the completion of the study.

\section{REFERENCES}

Bellefontaine, R., A. Ferradous, M. Alifriqui, and 0 . Monteuuis. 2010. Multiplication végétative de l'arganier, Argania spinosa, au Maroc: le projet John Goelet. Bois For. Trop. 304 (2) : 47-59.

Espinosa, J.G., and E.X. Briceno. 2008. Canker and twig dieback of Blueberry caused by Pestalotiopsis spp. and Truncatella sp. in Chile. Plant Dis. 92 (10) : 1407-1414.

Guba, E.F. 1961. Monograph of Pestalotia and Monochaetia. Harvard University Press, Cambridge, MA, USA. 342 p.

Hopkins, K.E., and M.P. McQuilken. 2000. Characteristics of Pestalotiopsis associated with hardy ornamental plants in the UK. Eur. J. Plant Pathol. $106: 77-85$.

Hu, H., R. Jeewon, D. Zhou, T. Zhou, and K.D. Hyde. 2007. Phylogenetic diversity of endophytic Pestalotiopsis species in Pinus armandii and Ribes spp.: evidence from rDNA and $\beta$-tubulin gene phylogenies. Fungal Divers. 24 : 1-22.

Jeewon, R., E.C.Y. Liew, J.A. Simpson, I.J. Hodgkiss, and K.D. Hyde. 2003. Phylogenetic significance of morphological characters in the taxonomy of Pestalotiopsis species. Mol. Phylogenet. Evol. 27 : 372-383.

Keith, L.M., M.E. Velasquez, and F.T. Zee. 2006. Identification and characterization of Pestalotiopsis spp. causing scab disease of Guava, Psidium guajava, in Hawaii. Plant Dis. 90 (1) : 16-23.

Luan, Y.S., Z.T. Shang, and Q. Su. 2008. First report of a Pestalotiopsis sp. causing leaf spot of blueberry in China. Plant Dis. 92 (1) : 171

McQuilken, M.P., and K.E. Hopkins. 2004. Biology and integrated control of Pestalotiopsis on container-grown ericaceous crops. Pest Manag. Sci. $60: 135-142$.

Metz, A.M., A. Haddad, J. Worapong, D.M. Long, E.J. Ford, W.M. Hess, and G.A. Strobel. 2000. Induction of the sexual stage of Pestalotiopsis microspora, a taxol-producing fungus. Microbiology $146: 2079-2089$.

Morgan, A., L. Boddy, J.E.M. Mordue, and C.W. Morris. 1998. Evaluation of artificial neutral networks for fungal identification, employing morphometric data from spores of Pestalotiopsis species. Mycol. Res. 102 (8) : 975-984. 
Nouaim, R., R. Chaussod, A. El Aboudi, C. Schnabel, and J.P. Peltier. 1993. L'arganier: essai de synthèse des connaissances sur cet arbre. Pages 373-388 in A. Riedacker, E. Dreyer, C. Pafadnam, H. Joly et G. Bory (eds.), Physiologie des arbres et arbustes en zones arides et semi-arides. Groupe d'étude de l'arbre. Observatoire du Sahara et du Sahel. John Libbey Eurotext, Paris, France.

Saar, D.E., N.E. Polans, P.D. Sørensen, and M.R. Duvall. 2001. Angiosperm DNA contamination by endophytic fungi: detection and methods of avoidance. Plant Mol. Biol. Rep. 19 : 249-260.

Thaung, M.M. 2008. Coelomycete systematic with special reference to Colletotricum. Mycoscience 49 : 345-350.

USDA. 2009. Agricultural Research Service. Fungal databases: Systematic mycology and microbiology. (Accessed: March 2010). http://nt.ars-grin.gov/fungaldatabases/.

Vallée, G., and R. Noreau. 1990. La "bouturathèque ": système de bouturage compact hors serre. Ministère de I'Énergie et des Ressources du Québec, Direction de la recherche. Note de rech. for. no $41.6 \mathrm{p}$.

Zhang, W., J.F. Wendel, and L.G. Clark. 1997. Bamboozled again! Inadvertent isolation of fungal rDNA sequences from Bamboos (Poaceae: Bambusoideae). Mol. Phylogenet. Evol. 8 (2) : 205-217. 